\title{
Justice as the Aim of/for Formation of Labor Law in Indonesia (A Review of Philosophy of Law)
}

\author{
Iron Sarira
}

\author{
Business Law Department, BINUS University \\ Corresponding author email: irons@binus.edu
}

\begin{abstract}
It is necessary to not only study the phenomenon of manpower in Indonesia from the normative perspective of law, but it is also necessary to expand to labor law in philosophical order which should be able to make the practitioners and involved parties understand the essence, implementation and the meaning of labor law, it means the law in the philosophical order, in the aspect of manpower is to create harmonious dynamic and equitable industrial relationships. The understanding of labor law as a goal is still not given enough attention and/or still underdeveloped, so that often there are positive law (what is written or as it is) nuances in the application of labor law from the making, approval and implementation, until decision at court level. It is expected that the use of philosophical juridical aspects in the implementation of labor laws regarding the praxis basis will make the implementation of labor laws to be fairer to the parties involved, by introducing good values from the normative, the sociological (experience), and the philosophical order. Philosophy is used as the balance for law enforcement dimension, which is conditioned as a reflection of justice as a moral will, so that positive law can realize certainty (juristische geltung) and usefulness (soziologische geltung). So, the philosophy of law essentially wants to explore the essence of the law. It wants to understand law as an appearance or manifestation of a principle that supports it as an embodiment of the ideals of law which in a legal sense is formed in accordance with the principle of justice which is desired in the implementation of aspects of industrial relations.
\end{abstract}

Keywords: Manpower, Philosophy, Justice

\section{INTRODUCTION}

The manpower in Indonesia is very phenomenal to be studied, both in terms of positive law, legal sociology, and multi-interdisciplinary from other academic disciplines, especially the philosophy of law which will be discussed in this paper.

Every year, a phenomenon of labor law related to the determination of minimum wage [1]. This problem becomes the object of workers' demonstrations where workers show their dissatisfaction toward the value set by the government (in this case the Local Government at the Provincial level or city/regency). In addition, manpower problems also occur in a holistic way which associated with the implementation of an outsourcing work system. Moreover, this work system is a diversion system from an existing work relationship that when the employer is relieved from his obligations to give severance pay to his employees over work agreements [2].

According to Agusmida, manpower issues have great impact based on some political reviews or studies. This means that policies affect the substance of the labor law formation so that the establishment of positive law in manpower becomes a legal product that is politically charged because legal policies are related to the development of national law [3]. When we look based on cybernetic relationships (value and energy flow) as expressed by Shidarta (2013:229-230) regarding the mutual influence of the legal system with other systems, the values by the legal system which form the actualization of the cultural system are accepted by the political system [4]. On the other hand, the economic system provides enrichment for the political system, so that it becomes the continuation of its relationship with the political system to realize the aims of its power to the functioning of the legal system using the law as an instrument of social order. This cybernetic relationship is described in Figure 1.

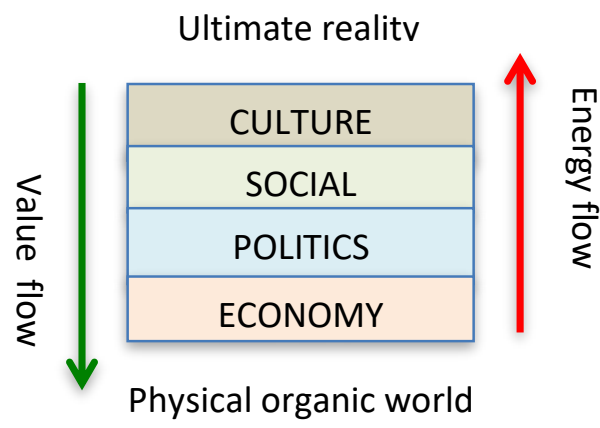

FIGURE 1. The cybernetic relationship of the legal system with other systems 
Based on Figure 1, it makes sense that labor law, as an object of our national law has to be regulated, gains influence in its formation regarding political interests as some sort of energy that is affecting it. So the manifestation of this influence will surely resulted in positive law of manpower which is considered to have no balance. In addition, the main purpose of the establishment of labor law is to abolish inequality in the legal relationship between the parties involved.

The formation of positive law in manpower as ius constitutum should be based on relation between the spirit of creating harmonious dynamic and equitable industrial [5]. The law should have a general function (including labor law) which is to create justice, certainty, and legal expediency as the embodiment of law enforcement aspects [6]. The law must be implemented and upheld/sustained, as the adage which states that "Let justice be done though the world perish" - fiat justitia et pereat mundus [7][8].

Some of Indonesian labor acts that currently form the ius constitutum regulate manpower aspects, such as: Act No. 13 of 2003 on manpower; Act No. 2 of 2004 concerning Industrial Relations Dispute Settlement; Act No. 1 of 1970 concerning Occupational Health and Safety (K3); Act No. 3 of 1951 about the Statement on the Supervision of Labor regulated in Act No. 23 of 1948, Jo. Presidential Regulation No. 21 Year 2010 on Labor Supervision; Act No. 24 of 2011 about the Social Security Organizing Agency; Minister of Manpower Regulation No. 17 of 2014 on the Appointment and Termination of Mediator and Working Procedures of Mediation; Government Regulation No. 8 of 1981 on the Protection of Wages. These acts are the products of positive law which exist as a legal system in a consistent way and the application becomes something that has a judicial enforceability (juristische geltung) [9][10][11].

The legal enforceability of positive law shows that the law fulfills the legal certainty as justiciable protection regarding arbitrary actions. It means that a person or legal subject will be able to obtain something that is expected in certain circumstances, because the public will experience order by having legal certainty [12]. The duty of the law is to give certainty to the people so that the people can experience justice and expediency of the law. In other words, legal enforce ability of labor laws from which some have been mentioned above, should give fair results of the implementation of the manpower aspects as its primary objective.
Manpower aspects are formed out of a legal relationship [12] in a labor agreement made between employers and workers called an employment relationship [13]. An employment relationship represents a dimension of agreement in the ceding of rights and obligations of the parties in an equivalent way, conform with the values of Pancasila and the 1945 Constitution as stated in Chapter X of Article 27 paragraph (2) that:

"Every citizen has the right to work and to live in human dignity"

The employment relationship constitutes a dimension that according to the Pancawarna (five colors) system in the labor law [14], namely:

1. Recruitment

2. Employment Relationships

3. Occupational Health

4. Occupational Safety

5. Social Security

The aspects used as of the employment relationship under the labor law system cannot be separated from the involvement of the parties who in cases related to the purpose of the establishment of labor laws experience the need for government involvement in addition to employers and workers. The Government has a role in creating harmonious, dynamic and fair industrial relations with a balanced foundation between the rights and obligations of the parties involved in the employment agreement. The relationship between these parties with the involvement of the government as a regulator and supervisor create great expectations for the area of manpower to reduce maximally the difference in the interests of the employers and workers from the disparity that was established in the history of labor law (read: slavery). So, if the aim of introducing labor laws is based on the aspects of industrial relations that have formed, then it is still important to go back to the essence and the presence of the parties to equally set aside interests in order to fairly achieve the results that are the goals of the management of business continuity.

The concept of justice represents the facts as the basis for any talk about law and its application [15][16][17]. Justice is an act that is not arbitrary, impartial, or biased. Moreover, justice contains the meaning that certain decisions and actions are based on objective norms, not subjective ones, therefore justice is seen as a relative concept [18]. Regarding the relationship between justice and law, it can be interpreted that the values of justice should become the foundation for the law in action that follows the current social reality. One particular purpose of law is the achievement of justice in society, so the 
benefits of the law is the law enforcement aspect. Justice discusses the system that forms it as the embodiment of an institutional authority in establishing positive law as procedural justice (formal) and substantive justice that discusses substantive positive law [19], as it is mentioned that (Black Law Dictionary, 7th edition, p. 869.):

"Justice fairly administered according to rules of substantive law, regardless of any procedural errors not affecting that litigant's substantive rights.

If this is interpreted, then what is right in a formal-procedural way can be contradicted in a substantive way and its substance contravenes justice. Justice in handling disputes by a legal procedure will be very visible from the legal construction built by the judge. Therefore, the judge as a law enforcement official in the authority of the Judicial Institute is the last bastion/fortress of justice [20].

A legal and judicial system cannot be established without paying attention to justice, because justice includes an intrinsic understanding (it contains a philosophical meaning, an essence) of a legal and judicial system. Therefore, the establishment of the system of law and justice should be guided by principles related to the interests of nation, which are represented by the beliefs about justice that live in the community. As the goal of the state and law is to gain as much happiness as possible for a large part of the community [18], which is legally closely related to the idea of how justice can be realized by bringing a dimension of truth or philosophical understanding in the implementation of the law in general and in particular in this study by talking about the man power aspects of law.

Justice is one of the problems in the study of the philosophy of law. This can be explained as the course in the philosophy of law that justice is one of the purposes of law most raised in the discussion related to the existing legal system. It was mentioned earlier that the purpose of law is not justice alone, but also the legal certainty and expediency. So ideally, law has to be a mix of the resultant of these three [21]. What is philosophy of law? The following question needs to be answered in the understanding of law as a science: what is jurisprudence? Mochtar Kusumaatmadja states that jurisprudence is the science of law in a particular country or community at a particular time [22]. Gustav Radbruch states that jurisprudence is bring to understood of the rechtphilosophie, law as a culture concept, is the reality the meaning of which is to serve the legal value, the idea of law. The objective of legal philosophy is to evaluate the law in terms of congruency with its only goal - "to realize the idea of law [23]. The object of the study of Jurisprudence is the valid law system, namely the conceptual system of legal rules and decisions from which the substantive parts are made positive by bearers of valid legal authority in the community or country that has implemented Jurisprudence. The implementation of Jurisprudence is focused on attempts to answer legal questions in order to find and offer an alternative to judicial settlements of certain social problems by pointing to and within a framework of valid positive law (macro and micro) [24].

The philosophy of law wants to explore the essence of law which means that it wants to understand law as the appearance or manifestation of an underlying principle (grant theory).The foundation in an open study on the philosophy of law as was mentioned before, is associated with the manifestation of a certain law dogmatic that is studied becoming something that has to be observed, that the philosophy of law becomes a study that provides clarity about whether "reality" in itself can be known and moreover how human behavior regarding this should be evaluated. The philosophy of law consists of two core statements, namely "what is the foundation of the binding force of law? And on the basis of what can we judge the fairness, predictability, and usefulness of these law products in their function as a social regulator of society? Is law dogmatic as legal apparatus of positive law need to be have a connection in answering questions about the force on the basis of a valid law dogmatic / positive law? And, based on what does this law enforcement function on the function of the law as a means of control in society? The thematic in this paper needs to be extended concerning the title on the discussion of this writing, which is related to legal dogma in the field of manpower related to justice which forms the basis of the aim of the formation of positive law.

Based on the background section regarding the research object, the identification of the issue is "How does justice fit within the labor laws that suitable with the philosophical values of Indonesia?"

\section{METHOD}

This research is a normative law research based on literature and field study on the formation of the labor law system by using descriptive analysis regarding the nature of the research [25].

The facts that occur in the implementation of the labor field constitute noumena on the condition of positive law and other interests that occur in the 
system of praxis of empirical aspects that make the development of the study of the substance of products of positive law in the field of labor in a philosophic scientific order become necessary. Concerning this matter, when it comes to this paper, the author made the following approaches:

a. The implementation of scientific concepts in the pyramid of science regarding the facts that occurred.

b. The application of reversible and irreversible causality as an overview on the concepts that were formed from these facts.

c. The formation of prepositions on the concepts that shape it. d. Primary and secondary data collection as support to confirm the nature of the descriptive study analysis conducted from various sources.

\section{RESULT AND DISCUSSION}

Manpower issues contain economic, social-welfare and social-political dimensions and other technical matters related to manpower which can be grouped in Indonesia's legal system as a field of scientific study of law both in civil law, criminal law, and state administration law [26]. The relation is as illustrated in the figure below:

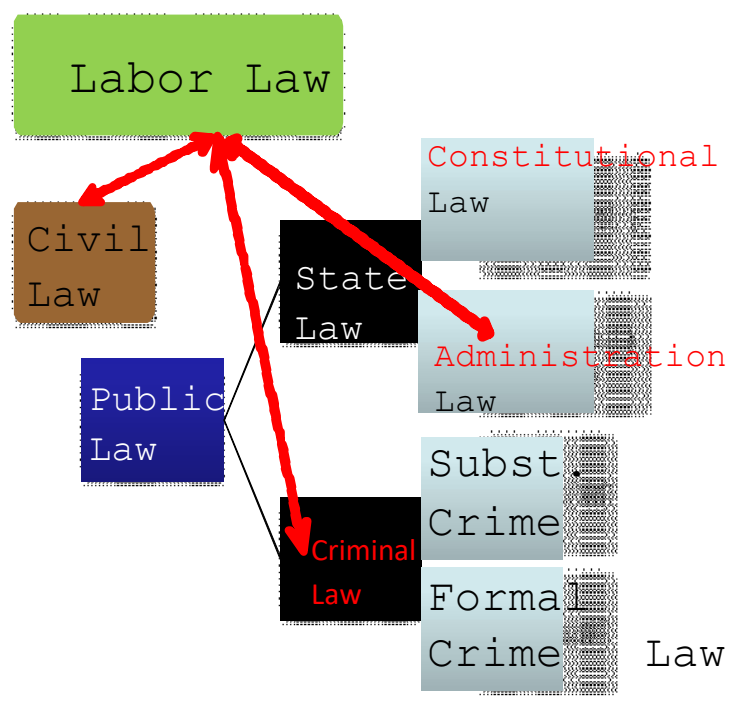

FIGURE 2 The place of labor law in the Indonesian legal system

The systems in the economic dimension of man power are built within the scope of experts and skillful workers following labor market needs. Employment is generated as wide as possible so that it can be used as (one) reference in measuring economic growth with the creation and the increase of purchasing power. The expansion of employment opportunities in the business world through various policies will necessarily bring the implications of changes in the economic and political system as a dimension that can differ from one another, or be in accordance with one another. The Indonesian government does not pay enough attention to the complexity of manpower issue, so that the emphasis that is often put forward is the economic growth issue. This issue affects the imbalance of the price value in the labor market in filling in job positions that should be carried out in view of the lack of manpower capability in terms of knowledge and expertise and this becomes the factor of the more and more isolated value of labor productivity. In addition to the inconsistency of rules in the field of manpower that seem to be made for the benefit of certain parties without representing the aspirations of the workers, there are political contents as a certain "message" from the parties that have a share in the economic arena of the country.

The positive law always seems to represent the employers or investors' interests under the pretext that economic growth can be maintained and continued. On the other hand the labor market's sales value is very limited. This phenomenon is ironic as labor laws are supposed to protect the workers from the arbitrariness that may arise from their employment relation, as to get rid of inequalities in the employment relationship between them [3]. Manpower is an important factor in the economic development of a country. This structure has an 
impact on labor law, so that the economic conditions can be portrayed as the essence [3] of the employment relation in the order of the application of positive law which covers the existing manpower conditions. Demographic analysis [27] on the structure of manpower is a scientific method all its own in studying the pattern of the labor laws formation in accordance with the expected values of the rules of the employment relationship, so that the generality of dogmatics law can provide a study of the aspects of the values in accordance with the aim of and for what reason the law was introduced.

The essence of a certain reality concerning the generality of labor law dogmatics creates complexity in the labor law system with various products of its regulations, it is increasingly becoming a certain apriority regarding the business world and other parties involved. The government can provide actualization concerning the practices of employment relation to become real and oriented to the rationalization of the truncating of legal function into a transparent and fair form. As an aspiration of law, Theo Huijberg suggests three purposes of law: first, maintaining public interest in the community; second, maintaining human rights; third, realizing justice in community life. Then the essence of positive law in manpower can be in line with the justice principle as a goal or realization of the rights of the parties. The principle of justice in its articulation can be described as the basis for fair treatment of humans who are citizens who live in the legal system of a country. As a principle that underlies a positive dogma in labor law, the principle of justice will strive to embody the essence of labor law, including the executive regulations so that it can be understood that the law dogmatics that are studied provide clarity about the sense that the mentioned "reality" is supposed to be assessed in. Justice is one of the law purposes that widely discussed throughout the course of history of philosophy of law. Ideally when speaking about the purpose of law in addition to creating justice, law should also reflect certainty as desired by the law itself, the law must also provide the benefit/truth as desired by the community/facts. Justice is an aim as desired by the moral.

Justice in positive labor law which describes the ontological dimension in the philosophy of law plays a role in the effort to respond to the essence of the reality of labor law as an understanding of an abstract norm into a concrete norm that provides control functions concerning the implementation of manpower practices in accordance with the legal essence that regulates them, like in the determination of the minimum wage that is set every year, the employer must provide standard wages in his company equivalent to the set wage, if this is not done, then the law provides other conditions such as postponement or elimination of the new minimum wage by providing the financial balance report of the company. The reflection of justice in positive law in the field of manpower which defines the epistemological dimension constitutes a certain theoretical study of law knowledge which should provide an understanding of the thought process in establishing positive law in the field of manpower [28]. The study of the meaning of reasoning in this dimension is an application of logic and/or abstract thinking patterns in solving problems or planning measures. Intuitionis [24] of the formation of positive law in the field of manpower should indeed be (law as such) made with regard to the aspect of certainty (rationalism) and the aspect of expediency (empiricism) concerning what is required for the making of the law for the parties involved, for example: a foundation for the formation of the Minister Regulation No. 19 of 2012 on Outsourcing (as formulated in the problem) whether it has the strength of the value of the positive law.

The determination regarding types of work (5 sectors) according Iftidah Yasar [29], that can be imposed on the following outsourcing activities, namely: catering services, transportation, cleaning service, security personnel, and the administration in the mining sector, will turn off outsourcing companies which are mostly small companies and accept work for a "work volume" that is not fixed. Concerns over the implementation of this government regulation is very reasonable given the variety of work sectors of service providers and types of work to be given to companies that provide services and types of jobs. Justice in the application of labor laws concerning the final dimension of legal philosophy regarding Axiology is reflected on the objectives to be achieved in legal reasoning that do not conflict with the principles of the law itself. Cases of manpower in the Industrial Relations Court illustrate that the judge should seek to discover the law in case the law is seen as a purpose, not just a function or service. The ability to know several things without the direct help of sensory or direct experience makes aspects of justice more difficult to be interpreted in this axiological dimension. Shidarta [30] explains that the Axiological dimension is very open to chances of disagreement, because it is the order of the dimension that the purpose of the establishment of positive law should have generality in a certain study concerning value aspects that are in accordance with the purpose of that law. It would 
be an axiom if human action was a function of his interest, which is motivated by the motivation (will) to answer the question of whether or not there is freedom in human will. This freedom is proof that the Axiological dimension is very open to disagreements in its regulations of practical implementation, related to products of labor law, therefore the example can be given that the policy on the establishment of an outsourcing work system has actually been set in several products of positive law, namely: the Indonesian Civil Code to be precise in Book III Chapter 7A, Section 1601 which divides work agreements into labor agreements and contracting work, Act 13 of 2003, Ministerial Decree $101 / \mathrm{MEN} / \mathrm{VI} / 2004, \quad$ Ministerial Decree 220/MEN/X/2004 (Both of these Ministerial Decrees have expired), Minister regulation 19, 2012, and Circular Letter. No. 04/2013, are open to interpretation among the involved and concerned parties, so that it becomes an issue of manpower that does not only become an issue at the microeconomic level (companies) but also at the macroeconomic level (state), for example: the case of outsourcing of PLN employees in Semarang.

The philosophy of law was instrumental in the understanding positive law that was made to create a legal product in the achievement of its ideal function to realize aspired law enforcement. Bismar Siregar has mentioned that "If I had to sacrifice legal certainty to maintain justice, then I would sacrifice it, because the law is only a means, while the goal is justice." [21] Justice is very important, but what is the real justice? (A discussion in the Ontological dimension) This was once answered during the time of Ulpianus (200 AD) and became the Justianus law book, which said that 'justice is the constant and perpetual wish to render to everyone his due' (iustitia est constans et perpetua voluntas ius suum cuique tribuendi). As the essence of the reality, the purpose of justice on positive law dogmatics has an understanding in the ontological dimension as an idea (idealism) on the law as a means of formation or realization of justice. The essence of law is a manifestation of the natural and universal principles of truth and justice.

When the essence of law is juxtaposed with the values of the philosophy of the Pancasila concerning the establishment of manpower law, then it can first of all be explained that the law was established to provide a sense of justice as required by the moral, law must have certainty in its formation, determination, and application, the law that already has that binding force should give a sense of usefulness to society. Legal certainty is something that is required by law and legal usefulness is something that is desired by the people. In the world of ideas that is based on the Pancasila, law should arise and be embedded naturally in the human soul, i.e. common sense and social conscience of man that requires humans to act and behave in certain ways, as formulated by the values of the Pancasila in the order regarding the embodiment of the balance of rights and obligations [31]. This turns human behavior into the essence of justice in its efforts to establish labor laws while still providing a balanced portion for positive law in actualizing the values of Pancasila in implementing the rights and obligations based on the principle of conformity which requires the implementation of harmony in social life. As manifest from the ontological dimension related to this principle, besides being based on truth considerations and the rules of law, the solution of concrete problems must also be accommodated in community processes as a whole by taking the feelings that really live in society into account [31]. The existence of positive law in the field of manpower in an ontological way places law on a very abstract level, so that explaining the existence of justice in the eyes of the philosophy of law needs to open a space for morality as a condition imposed by one of the ideologies in the philosophy of law i.e. Natural Law [32].

Natural law [33][34][35][36][37][38] ideology has the functionality to measure the validity of a positive law with the highest measure not from the positive law itself but opened up higher, so that it transgresses the boundaries of logical human thought. Reasoning in an epistemological dimension related to justice concerning the creation of labor law is not seen from the terminology of legal reasoning, but from the moral identification in the formation of positive law by the ruler known for morale reasoning [32]. Rationality becomes the substance that forms in applying the criterion from the side of morality to positive law [39][40][41][42][43][44] in the field of manpower over what is universally valid and eternal. The understanding of harmonious, dynamic and fair is an example that manpower laws are universal to the final (eternal) purpose as morale content regarding true justice that becomes an effort in the establishment of labor laws. Meanwhile, the axiological dimension concerning justice in the establishment of labor laws provides a constellation regarding the basis and origin of justice itself which becomes the aim desired by the moral. Positive law must return to terminology conceptualization, namely ponere-posui-positus [45][46] which in law means that to give certainty it is interpreted as it is 
laid down so that the affairs of justice/ legal expediency are dependent on the laws that have been laid down [4].

\section{CONCLUSION}

As a conclusion, the following answers can be given to the issue concerning a narrative conclusion on the existence of the philosophy of law in the principles of justice related to the establishment of labor laws in Indonesia:

1) Philosophy of Law should be more optimally included in any formation of positive law in the field of manpower. This law does not merely become a service to the practical problems in the field which cannot afford justice for the parties regarding dispute or quarrel. (Aspects of the Ontological dimension of the Philosophy of Law in the order of the search for the essence of the law as such.)

2) The makers of positive law in the field of manpower should have an understanding of the thought processes in forming a positive law in the field of manpower, concerning the reasoning patterns in the application of logic and/or the patterns of abstract thinking to solve a problem or act of planning. Intuition needs to be used in making this positive law, as a reflection of the problems that have occurred so that the law is no longer running behind reality, but can reach its goal to be useful in its application in its practical suitability. (The aspect of the Epistemological dimension on how the positive law in the field of manpower is represented according to the method or manner in practical order (empirical).

3) In case of the principles of law that are not in conflict with the objectives of law to be achieved in this axiological dimension, the axiom regarding the interests of the parties in the field of manpower needs to be achieved as the embodiment of the values of justice, certainty, and usefulness. So the chance of conflicts caused by differences in interpretation or the inability of positive law to solve the problems which occur is no longer something that is increasingly difficult to be realized, because the concept of judge made law can be executed in this dimension. (Aspects of the axiological dimension about the openness toward disagreements, because it is the order of the dimension that the purpose of the establishment of positive law should have generality in a study of aspects of the value that corresponds to the purpose of and for what reason the law was made).

\section{REFERENCES}

[1] Pierson, F, The Determination of Minimum Wage Rates, The American Economic Review, Vol. 30, No. 1, Part 1 (Mar., 1940), pp. 72-81

[2] Weiss, G., D, Dismissal Pay Provisions in Major Bergaining Agreements, Monthly Labor Review, Vol. 80, No. 6 (June 1957), pp. 707-712.

[3] Agusmida, 2011, Dilematika Hukum Ketenagakerjaan-Tinjauan Politik Hukum, Medan, Sofmedia.

[4] Shidarta, 2013, Hukum Penalaran dan Penalaran Hukum, Yogyakarta, Genta.

[5] Leonertz, J., R, En Merge Du “Constitutum Constantini': Contibution A L'Histoire Du Texte, Revue des Sciences philosophiques et théologiques, Vol. 59, No. 2 (Avril 1975), pp. 289-294

[6] Mertokusumo, S, December 2007, Mengenal Hukum Suatu Pengantar, Yogyakarta, Liberty.

[7] Knapp, C, Fiat Iustitia Ruat Caelum, The Classical Weekly, Vol. 18, No. 14 (Feb. 2, 1925), pp. 110-111.

[8] Heussen, B, Fiat Justitia-Pereat Mundus: Uber die Todlichen Gefahren Falscher Ubersetzungen, Zeitschrift für Rechtspolitik, 44. Jahrg., H. 8 (24. November 2011), pp. 251-252.

[9] Chung, E, The Judicial Enforciability and Legal Effect of Treaty Reservation, Understandings, and Declarations, The Yale Law Journal, Vol. 126, No. 1 (OCTOBER 2016), pp. 170-241.

[10] Reitz, K.R., The Enforciability of Sentencing Guidslines, Stanford Law Review, Vol. 58, No. 1, A More Perfect System: Twenty-Five Years of Guidelines Sentencing Reform (Oct., 2005), pp. 155173.

[11] Kilejian, M., et.al., Enforciability of Choice of Forum and Choice of Law Provisions, Franchise Law Journal, Vol. 32, No. 2 (FALL 2012), pp. 81-94.

[12] Soeroso, R, November 2006, Pengantar Ilmu Hukum, Jakarta, Sinar Grafika. 
[13] Uwiyono, A, et.al., February 2014, AsasAsas Hukum Perburuhan, Jakarta, RajaGrafindo Persada.

[14] Soepomo, I, 1999, Pengantar Hukum Perburuhan, Jakarta, Djambatan.

[15] Ginsberg, M, The Concept of Justice, Philosophy, Vol. 38, No. 144 (Apr., 1963), pp. 99-116.

[16] Fried, C, Natural Law and The Concept of Justice, Ethics, Vol. 74, No. 4 (Jul., 1964), pp. 237-254.

[17] Rubinstein, D, The Concept of Justice in Sociology, Theory and Society, Vol. 17, No. 4 (Jul., 1988), pp. 527-550.

[18] Santoso, H.M. Agus, September 2012 Hukum, Moral dan Keadilan-Sebuah Kajian Filsafat Hukum, Jakarta, Kencana.

[19] Sanusi, A, November 2009, Keadilan Substantif dan Problematika Penegakkannya, Varia Peradilan-Majalah Hukum Tahun XXV No. 288.

[20] Adji, I. Seno, 2007, Arah Sistem Peradilan Pidana, Jakarta, Kantor Pengacara dan Konsultan Hukum Prof. Oemar Seno Adji, SH \& Rekan.

[21] Darmodiharjo, D, et.al., May 2006, PokokPokok Filsafat Hukum-Apa dan Bagaimana Filsafat Hukum Indonesia, Jakarta, Gramedia.

[22] Kusumaatmadja, M, October 2013, dapat dibaca dalam Bernard Arief Sidharta, Ilmu Hukum Indonesia, Yogyakarta Genta Publishing.

[23] Radbruch, G, 2000, An Extraordinary Legal Philosopher, Journal of Law \& Policy, Washington University, Vol. 2.

[24] Sidharta, B. Arief, October, 2013, Ilmu Hukum Indonesia, Yogyakarta, Genta Publishing.

[25] Soekanto, S, 2007, Pengantar Penelitian Hukum, Jakarta, UI-Press.

[26] Khakim, A, 2007, Pengantar Hukum Ketenagakerjaan Indonesia, Bandung, Citra Aditya Bakti.

[27] Sumanto, 2014, Hubungan Industrial Memahami dan Mengatasi Potensi Konflik Kepentingan Pengusaha-Pekerja Pada Era Modal Global, Yogyakarta, CAPS.
[28] Stanley, J, et.al., 2001, Knowing How, Journal of Philosophy.

[29] Yasar, I, October 2013, Apakah Benar Outsourching Bisa Dihapus?, Yogyakarta, Pohon Cahaya.

[30] Shidarta, March 7 2014, materi perkuliahan Program Doktor Ilmu Hukum - UNPAR.

[31] Kartohadiprodjo, S, January 2010, Pancasila Sebagai Pandangan Hidup Bangsa, Gatra Pustaka.

[32] Shidarta, 2007, Aliran Hukum Kodrat, Jakarta, UPT Penerbitan Universitas Tarumanagara.

[33] J. Hughes, G, Natural Law, Journal of Medical Ethics, Vol. 2, No. 1 (March 1976), pp. 34-36

[34] Mark, J, Natural Law, Earth Island Journal, Vol. 27, No. 1 (Spring 2012), pp. 40-46

[35] Holmes, O. Wendell, Natural Law, Harvard Law Review, Vol. 32, No. 1 (Nov., 1918), pp. 40-44

[36] Oandasan, W, Natural Law, Wicazo Sa Review, Vol. 1, No. 1 (Spring, 1985), p. 35

[37] Leach, N, Natural Law, The Furrow, Vol. 18, No. 12 (Dec., 1967), pp. 726-727

[38] F. Creegan, R, Natural Law, The Journal of Philosophy, Vol. 43, No. 5 (Feb. 28, 1946), pp. 124-132.

[39] Nonet, $\mathrm{P}$, What is Positive Law?, The Yale Law Journal, Vol. 100, No. 3 (Dec., 1990), pp. 667-699

[40] Cotta, S, Positive Law and Natural Law, The Review of Metaphysics, Vol. 37, No. 2 (Dec., 1983), pp. 265-285

[41] Ago, R, Positive Law and International Law, The American Journal of International Law, Vol. 51, No. 4 (Oct., 1957), pp. 691-733

[42] Jenkins, I, The Genesis of Positive Law, ARSP: Archiv für Rechts- und Sozialphilosophie / Archives for Philosophy of Law and Social Philosophy, Vol. 50, No. 1 (1964), pp. 1-21

[43] M. Platt, C, Positive Law and Other Law, Political Science Quarterly, Vol. 9, No. 1 (Mar., 1894), pp. 53-63

[44] Williamson, C, The Roman Aristrocracy and Positive Law, Classical Philology, Vol. 85, No. 4 (Oct., 1990), pp. 266-276

[45] W. Mather, M., Quo Mondo Laciendi Verbi Composita in Praesentibus Temporibus 
Enuntiaverint Antiqui et Scripserint, Harvard Studies in Classical Philology, Vol. 6 (1895), pp. 83-151.

[46] Yukio, I, Pseudo-Rabanus Super Porphyrium, Archives d'histoire doctrinale et littéraire du Moyen Age, Vol. 75 (2008), pp. 43-196. 